\title{
PERAN KEPEMIMPINAN KRISTEN MEMBANGUN DIALOG ANTAR UMAT UMAT BERAGAMA
}

\author{
Daniel Ronda
}

\section{PENDAHULUAN}

Kata "Dialog" adalah kosakata penting untuk sebuah rekonsialiasi, pencerahan atas suatu masalah, dan jembatan penciptaan hubungan, serta kehidupan berbangsa yang harmonis dan damai. Bila dialog dihubungkan dengan agama-agama, maka seluruh eksistensi agama menjadi obyek sekaligus subyek dari pembahasan. Maksudnya, agama diteropong sebagai suatu pengajaran, doktrin dalam berhubungan dengan agama lainnya, tetapi sekaligus agama sebagai suatu pedoman dalam menentukan arah dialog itu sendiri. Dialog agama-agama yang kemudian diwadahi dalam diskursus teologi agama-agama (theologia religionum) bukanlah barang baru dalam dunia berteologi di Indonesia. Namun disadari memang dialog ini bukanlah sumber satu-satunya semua penyelesaian masalah konflik sosial di Indonesia. Konflik bernuansa agama yang besar setelah reformasi di Indonesia pertama kali muncul di Ambon di tahun (1999, 2001), dilanjutkan peristiwa Poso (2001), dan berkembang dengan pembakaran serta pengeboman gereja-gereja di berbagai kota di Indonesia selama bertahun-tahun. Belum lagi meningkatnya sikap intoleransi dalam kehidupan bermasyarakat saat ini akibat kontestasi politik seperti yang terjadi pada kasus Pilkada DKI Jakarta yang menimpa Ahok atau Basuki Tjahaja Purnama. Bahkan Setara Institute menyebutkan bahwa ada 10 kota yang palin intoleran di Indonesia yaitu Tanjung Balai (skor: 2,817); 2. Banda Aceh (skor: 2,830); 3. Jakarta (skor: 2,880); 4. Cilegon (skor: 3,420); 5. Padang (skor: 3,450); 6. Depok (skor: 3,490); 7. Bogor (skor: 3,533); 8. Makassar (skor: 3,637); 9. Medan (skor: 3,710); 10.Sabang (skor: 3,757) (Lihat Inge Klara Savitri, "Jakarta Paling Intoleran Ketiga, Ini Hasil Survei Selengkapnya")

Begitu juga laporan dari Human Right Watch tahun 2013 sejak pemerintahan Susilo Bambang Yudoyono mengalami kemunduran. Misalnya pada tahun 2012, ditemukan 264 kasus tindakan kekerasan terhadap kelompok-kelompok minoritas agama dan pada tahun 2013 meningkat menjadi 243 kasus. Disebutkan bahwa korbannya mencakup beberapa kelompok seperti Kristen, Ahmadiyah dan Syiah (Cahyo Pamungkas, 286). Lebih lanjut sebagaimana ditulis Cahyo Pamungkas tentang The Wahid Institut tahun 2013 menyebutkan bahwa pada tahun 2013 masih dijumpai 106 tindak intoleransi beragama. Intoleransi yang dilakukan antara lain adalah penuutupan tempat ibadah (28 kasus), diikuti pemaksaan keyakinan (19 kasus), penghentian kegiatan keagamaan (15 kasus) dan kriminalisasi atas dasar agama 14 kasus. Sementara intoleransi oleh kelompok ormas yang paling banyak terjadi adalah serangan fisik (27 kasus) dan penutupan gereja (25 kasus) (Ibid).

Kasus-kasus itu menunjukkan bahwa dialog ini masih perlu diperjuangkan dan perjalanannya masih panjang. Harus dimengerti bahwa dialog hanya salah satu bagian dari penyelesaian sosial keagamaan di Indonesia, karena ada masalah kesenjangan ekonomi dan keadilan sosial juga yang membuat konflik sosial dengan memakai agama tidak pernah tuntas. Walaupun demikian, tetap pemimpin Kristiani diharapkan dapat terus mendalami upaya dialog dalam konteks berbangsa dan bernegara di Indonesia. Dalil kepemimpinan Kristen sudah jelas, bahwa kepemimpinan itu tidak hanya di dalam konteks gereja tapi juga sudah harus memiliki pengaruh sampai kepada masyarakat. 
Henry Blackaby dalam bukunya menjelaskan bahwa "To be a spiritual leader is just as essential in the marketplace as in the church (untuk menjadi pemimpin rohani sama pentingnya baik di dunia pasar maupun di gereja" (Hal. 17). Lebih lanjut dikatakannya, "Spiritual leaders can influence all people, not just God's people (pemimpin rohani dapat mempengaruhi semua orang dan bukan hanya umat Tuhan di gereja)" (Blackaby 20-23). Pemimpin memiliki peran signifikan dalam mengembangkan dialog damai antar umat beragama.

Tulisan ini mengangkat peran kepemimpinan dalam dialog umat beragama dengan tujuan untuk dapat kritis atas dialog yang dibangun selama ini. Bagian tukisan ini akan mengevaluasi sikap teolog terhadap pluralisme yang dikembangkan dalam teologi agama-agama, persoalan yang dihadapi dalam berdialog di Indonesia dan dasar teologis dalam mengembangkan dialog, peran pemimpin ke depan dialog antar agama.

\section{EVALUASI TERHADAP TEOLOGI AGAMA-AGAMA}

Sebelum memberikan kajian atas peran pemimpin Kristen atas dialog antar umat beragama, maka perlu ada kajian secara garus besar atas teologi agama-agama. Teologi agama-agama berkeyakinan bahwa jika teologi tentang agama dibuah menuju pluralis maka akan menjadi jalan bagi dialog yang baik antar umat berama. Benarkah asumsi ini? Dalam teologi agama-agama dikembangkan tesis adanya realitas pluralitas masyarakat dan corak keagamaan. Ini suatu realitas yang tidak pernah terbantahkan. Persoalan yang perlu mendapatkan evaluasi kritis adalah dikembangkan konsep teologi pluralisme yaitu bahwa semua agama memiliki kebenaran dan diupayakan untuk mengembangkan kebersamaan sehingga memiliki satu ibadah yang dicampurkan. Secara filosofis pluralisme tidak mereduksikan segala sesuatu pada satu prinsip terakhir, melainkan menerima adanya keragaman. Akar dari teologi pluralisme ditemukan pada gereja Teologi Liberal yang mulai dikembangkan oleh Friedrich Schleiermacher (1768-1834) bahwa agama adalah pengalaman pribadi yang subyektif dan tidak ada obyektivitas kebenaran. Pendekatan ini terus dikembangkan sehingga menjadi suatu teologi pluralisme yang intinya menerima semua agama sama. Ada juga konsep yang berbeda yaitu inklusivisme, di mana agama saya adalah kebenaran sedangkan di dalam agama lain mereka bisa menemukan Kristus (konsep Kristen) atau menemukan ketundukan kepada Allah (konsep Islam). Sehingga muncul konsep Kristen anonim atau Islam anonim, dan seterusnya dalam melihat agama lainnya.

Tetapi perlu diberi catatan tentang konsep ini pluralisme teologi (Bandingkan dengan Andi Ramli, 5). Pertama, teologi pluralisme sangat menunjung kemajemukan yang menjadi dasar membangun dialog, tetapi kemudian kemajemukan itu sendiri dilihat sebagai konsep yang negatif. Artinya, perbedaan aliran dalam keagamaan dipandang sebagai kepicikan dan sumber masalah konflik. Kelompok pluralis justru menuduh perbedaan teologi menjadi masalah. Kaum pluralis Kristen misalnya, tidak memberi ruang kepada "fundamentalisme" (baca dalam konteks Kristen yang biasanya ditujukan kepada kaum "Pentakosta, Karismatik, dan Evangelikal") untuk menyuarakan isi hatinya. Seringkali mereka menjadi sasaran empuk kritik, apalagi memakai kritik dengan argumen strawman, di mana si pengkritik "membantu" membangun konsep "fundamentalisme" itu lalu bangunan itu dihantam oleh argumen yang dibangunnya sendiri, yang bukan secara jujur mendalami kepelbagian teologi dalam Kekristenan. Misalnya pandangan Ioanes Rahmat yang memberikan kritik terhadap konsep fundamentalisme terhadap Alkitab yang intinya atau secara implisit dia mengungkapkan bahwa fundamentalisme akan menimbulkan banyak persoalan terutama kesejukan dalam kehidupan umat beragama (Ioanes Rahmat, 25). Jadi tuduhan seperti ini sendiri sudah menyalahi prinsip pluralisme yang dianutnya. Pada 
prinsipnya bahwa pluralisme agama menunjukkan adanya koeksistensi agama-agama yang memungkinkannya hidup secara damai (Wardani 47). Keberadaan agama dihormati keberagamannya dan membangun dalam dialog dengan dasar kesamaan teologis.

Kedua, teologi pluralisme berupaya membangun definisi dan fungsi agama yang sama sehingga agama lalu kehilangan identitasnya. Maka muncullah sinkretisme dan relativisme agama yang hanya diminati kaum "elite" teolog tetapi di akar rumput menolak pandangan itu. Karenanya perlu mendengar apa yang dikatakan Banawiratma, bahwa kita perlu menyadari bahwa teologi itu harus dihayati dalam sikap rendah hati, integritas, dan keterbukaan (Banawiratma, 41). Tanpa integritas dan ditambah identitas, maka dialog agama hanya mengarah kepada "oportunisme yang dangkal" (Banawiratma 41) . Karenanya dalam mengembangkan teologi agama-agama perlu dicari suatu solusi yang dapat diterima semua pihak dan seluruh lapisan umat beragama. Ternyata bahwa teologi pluralisme belum mendapatkan tempat dalam akar rumput masyarakat gereja, sehingga perlu ada suatu pendekatan baru dalam mengembangkan dialog bersama.

\section{BEBERAPA PERSOALAN DALAM DIALOG AGAMA-AGAMA}

Dari usaha mengembangkan dialog, seringkali yang terjadi malah konflik seperti halnya yang dialami bangsa Indonesia. Dalam mengembangkan dialog agamaagama, maka selalu ada persoalan yang muncul. Pada bagian ini, penulis mencoba mengidentifikasi persoalan itu:

Pertama, adanya tekanan politik yang memakai agama sebagai kendaraan untuk mencapai kekuasaan sehingga ada tekanan dari pemerintah dalam setiap bidang keagamaan (Lihat Abd Rahim Ghazali). Di sini agama sebagai alat mencapai kekuasaan, dan pada akhirnya dimensi kekerasan yang ditonjolkan dalam berhubungan dengan agama-agama lain. Hal ini nampak dalam sejarah, maupun konteks dewasa ini seperti berbagai muncul ormas keagamaan yang dipakai oleh alat politik untuk mencapai tujuan kekuasaan. Begitu juga ketika kekuasaan diperbesar, sehingga peran agama dibatasi lewat dieksploitasi, sehingga kerukunan yang ditawarkan hanya bersifat seremonial belaka (Zakharia Ngelow, 130). Perjalanan politik menggunakan agama sebagai kendaraan mencapai kekuasaan terus akan mewarnai kehidupan berbangsa di Indonesia dan ini yang patut mendapatkan perhatian yang sangat serius.

Kedua, secara khusus dalam konteks Indonesia, hubungan Islam-Kristen yang memang tidak harmonis dalam sejarah, sejak mulainya invasi Islam ke Eropa, berlanjut ke perang salib, dan adanya persaingan dalam menguasai perdagangan di Indonesia (kisah Portugis, Belanda dengan saudagar, sultan Islam). Hubungan itu berlanjut dalam konteks perpolitikan di Indonesia, sejak kemerdekaan dengan insiden piagam Jakarta, di mana ada perasaan menang kalah, ada kelompok nasionalis-islami, dan seterusnya (Bdk. Martin L. Sinaga, 7-9). Ini berarti relasi antar agama di Indonesia harus diperhatian khusus antara hubungan dengan Islam akibat dari perjumpaan yang panjang baik yang bersifat damai maupun konflik antar pemeluk kedua agama.

Ketiga, adanya eksklusivisme yang ekstrim dari pihak Kristen sendiri, di mana melakukan tindakan pelayanan tanpa etika dan etiket, agresivitas yang membuat tersinggung pihak lain, dan militanisme dalam usaha misi. Tentu yang penulis maksud dengan militanisme adalah bukan tindakan kekerasan, tetapi cara-cara yang membuat misi yang membuat keresahan banyak orang, dan si pelaku merasa ini adalah bagian dari penderitaan Kristus yang dinubuatkan kepadanya. Walaupun demikian pada saat yang sama penulis menolak kritik yang membabi buta terhadap kelompok eksklusif, 
di mana soal kerohanian mereka adalah kelompok yang membangunkan gereja untuk kembali kepada misi utamanya. Namun harus diakui bahwa kelompok eksklusif sangat "berani" sehingga perlu ada hikmat khusus, misalnya gembar-gembor slogan dengan poster besar-besaran, booklet dan buletin-buletin yang radikal, penggunaan media sosial bahkan YouTube untuk menyerang agama lain. Berkaca dari kelompok Kristiani sendiri, maka ini memang akan menimbulkan kerikil-kerikil dalam berdialog dengan agama lain

Tentu akan ada lagi persoalan yang mungkin akan muncul dalam dialog ke depan, termasuk di era dunia digital yang perlu mendapat kajian penelitian tersendiri yaitu bagaimana peran pemimpin Kristen dalam mengembangkan dialog di era dunia digital. Yang jelas lewat media sosial telah tumbuh ketakutan adanya rongrongan agama, perpindahan umat, isu Islamisasi dan Kristenisasi, dan banyak yang mencul dalam media sosial. Berarti bahwa perjuangan dialog tidak akan selesai dalam waktu singkat dan dalam perjalanannya akan menemukan terus berbagai hambatan. Dialog adalah perjuangan masih panjang ke depan yang membutuhkan kesabaran dan komitmen untuk merawat bersama.

\section{DASAR TEOLOGIS MENGEMBANGKAN DIALOG}

Seperti yang disebutkan di atas, konsep pluralisme bahkan inklusifisme mungkin akan menemukan kendala bila berhadapan dengan kelompok akar rumput. Bukan hanya itu, pihak agama lain pun seperti Islam tidak selalu sepaham dengan pandangan pluralis, ataupun inklusifis seperti Nurcholish Majid, dsb. Bahkan munculnya radikalisme agama-agama seperti di kalangan Islam-Kristen-Hindu, membuat dialog yang diupayakan sepertinya mengalami kemunduran yang signifikan. Karena akibat dari konflik yang muncul misalnya, dapat membuat luka kembali menguak. Maka saya ingin menawarkan dasar teologis yang partikularistransformatif (Alister McGrath). Partikularis artinya nilai-nilai keagamaan sendiri kita hargai dan hayati, seperti keunikan karya penyelamatan Yesus yang relevan bagi semua manusia, tetapi pada saat yang sama menghargai sesama manusia sebagai ciptaaan Allah. Bahwa kemudian mereka memiliki suatu keyakinan yang berbeda, maka itu adalah dalam kedaulatan Allah. Sedangkan transformatif artinya kita bersama agama-agama lain berdialog secara jujur dan terbuka, serta berjuang memperbaiki soal-soal kemanusiaan berdasarkan nilai-nilai keagamaan.

Bagaimana dengan usaha pekabaran Injil yang merupakan perintah Allah sendiri? Bila itu perintah, maka itu bersifat mandatoris bagi orang percaya. Tetapi ada tiga hal yang perlu dicatat. Pertama, usaha PI haruslah bersifat holistik, dan bukan hanya konsep verbal. Artinya, seluruh kehidupan manusia itu adalah alat kesaksian. Kedua, kita hanya diminta mewartakan, sebagai saksi dan bukan memaksakan kehendak. Ketiga, perlunya menghormati hak asasi sesama manusia. Allah memanggil kita sebagai alat kesaksian dan bukan alat untuk memaksakan keyakinan kita.

Yesus sendiri adalah pribadi pembawa damai, yang membiarkan diri menjadi alat kesaksian yang hidup baik dengan pengajaran dan perbuatan. Ia tidak pernah membuat orang terpaksa datang kepadaNya dengan ancaman. Bahkan Dia pergi dengan segala lapisan masyarakat (pemungut cukai, Farisi, dsb.) untuk berbicara kepada mereka.

Sedangkan pernyataan keekslusifan yang dicatat dalam Injil Yohanes dan Injil lainnya, harus dicatat sebagai suatu keunikan karya Kristus bagi yang percaya kepadaNya, dan pada saat yang sama tawaran itu datang dalam bentuk-bentuk damai kepada semua manusia dan dalam bentuk perjuangan kemanusiaan. 


\section{PERAN PEMIMPIN MEMBANGUN DIALOG}

Bila melihat hambatan yang ada, maka ada ada beberapa sikap yang bisa diambil. Jalan dialog bukan satu-satunya penyelesaian konflik berwarna agama, dan tidak mudah membangun dialog tetapi selalu ada harapan karena memang bangsa ini terkahir majemuk. Maka dalam dialog antar agama perlu memiliki beberapa agenda yang mana pemimpin Kristen menjadi garda utama untuk membangunnya:

Pertama, perlu mengembangkan semangat persaudaraan sebagai bangsa Indonesia (Gazhali, 3 \& 5). Rasa persaudaraan ini adalah memiliki dasar teologis yang kuat, bahkan dasar yang kuat yaitu sebagai bangsa Indonesia. Suatu yang ironis dan menyakitkan bahwa perang atas nama agama akhirnya membuat orang membunuh sesama bangsa, di mana berdampak negatif terhadap citra bangsa Indonesia sendiri. Bahwa agama adalah bagian dari ekistensi berkehidupan namun

Kedua, kurikulum di sekolah-sekolah perlu meningkatkan pendidikan yang pluralis secara sosial dengan menekankan aspek emansipatoris, transformasi sosial, mengapresiasi humaniora, dan pembentukan kesadaran peserta didik (Ahmad Fuad Fanani, 3-5). Ini harus menjadi agenda setiap pendidik, tanpa memandang dari agama manapun. Berkaitan dengan pendidikan PAK di sekolah-sekolah teologi maka pendidikan yang plularis dengan memberikan kesadaran keberagaman bangsa Indonesia dan menghargai manusia sebagai ciptaan Tuhan.

Ketiga, dialog harusnya menghasilkan "religious literacy" atau melek agama lain sehingga bisa melihat wawasan yang lebih luas (Aloys Budi Purnomo, 3-5). Pendidikan teologi seharusnya berisi bukan hanya kurikulum perbandingan agama, tetapi mengizinkan tokoh agama lain berbicara tentang topik-topik agamanya sehingga bisa memahami agama lain lebih baik. Inisiatif harus dimulai dari para pemimpin baik di gereja maupun di sekolah teologi.

Keempat, para pemimpin Kristen sudah saatnya kembali untuk mengembangkan kebersamaan dalam memperjuangkan masalah kemanusiaan, keadilan sosial, dan ekologi (Ngelow, 132). Ini agenda yang penting dalam dialog, ketimbang memperdebatkan ajaran-ajaran dengan tafsiran yang sempit, padahal isu besar dalam masalah berbangsa adalah masalah lingkungan hidup termasuk hutan sudah dibabat sehingga rakyat dimiskinkan, keadilan sosial diinjak-injak, ketimpangan ekonomi yang masih terasama dan itu menghasilkan manusia miskin. Ini nampaknya tidak mendapat tempat yang berarti dalam pembangunan Indonesia yang hanya berbasiskan kepada kekuasaan. Artinya permasalahan kemanusiaan dan sosial negara bukan semata urusan negara, namun menjadi tanggung jawab pemimpin gereja. Kesenjangan sosial dapat menjadi materi dialog yang dapat menguatkan peran gereja dan agama dalam mensejahterakan umat.

Kelima, secara internal dalam menghadapi eksklusivitas kelompok Kristiani, patut dengan sabar menghadapi mereka serta sekaligus menjadi refleksi untuk berkaca pada diri. Bila gereja terlalu berfokus kepada persoalan humanistis, maka gereja akan kehilangan dimensi spiritualitas yang diperlukan manusia Indonesia. Ketika rasio diangkat dan dipuja dalam menjawab persoalan biblika, kita menghilangkan kebutuhan dasar semua manusia yaitu dimensi rohani (Liem Khiem Yang, 17-23). Pada dasarnya dialog antar umat Kristen perlu ditingkatkan dalam keberagaman teologi dan saling 
menghargai perbedaan berteologi. Upaya itu sudah dilakukan tetapi terus dirawat dan dikembangkan.

\section{KESIMPULAN}

Masa depan bangsa sangat bergantung juga atas peran para pemimpin Kristen dalam terus membuka diri kepada dialog. Usaha-usaha menutup diri dan kesempitan berpikir adalah pola pikir yang berbahaya. Gereja harus berani membangun dialog dan bukan menunggu adanya inisiatif pihak lain mengadakan dialog, karena dalam dialog ada panggilan bersaksi dan membirkan Kristus berkarya dalam dialog yang sehat dan membangun. Tentu ada hal yang membuat kita optimis, bahwa teologi kita membuka peluang bagi dialog, dan kultur masyarakat kita yang inklusif (dalam konteks budaya) membuat prospek dialog agama ini menjadi lebih baik untuk ke depan. Tinggal pemimpin gereja rela membuka diri dalam membangun dialog dalam kedalaman dan komprehensif, yang membawa kesejahteraan dalam berbangsa dan bernegara.

Bibliografi:

Abd Rohim Ghazali, Pluralitas atau Polaritas. Kompas, 1 Maret 2002, 3\&5

Ibid. Konflik dan Patologi Sosial, karena Formalisme atau Politisasi Agama. Kompas, 1 Desember 2001: 33.

Ahmad Fuad Fanani, Menyoal Pendidikan Agama Pluralis. Kompas, 5 Desember 2001: $3 \& 5$.

Aloys Budi Purnomo. "Religious Literacy" dan Tantangan Pluralisme Agama. Kompas, 9 November 2001: 3\&5.

Andi M. Ramly. "Dialog Agama Dalam Paradigma Inklusif-Transformatif”. Kompas, 19

B.J. Banawiratma, "Mengembangkan Teologi Agama-Agama" dalam Meretas Jalan Teologi Agama-Agama di Indonesia (Theologia Religionum) oleh Balitbang PGI, ed. Jakarta: BPKGM, 2000.

Cahyo Pamungkas "Toleransi Beragama dalam Praktik Sosial: Studi Kasus Hubungan Mayoritas dan Minoritas Agama di Kabupaten Buleleng” Jurnal Episteme Vol. 9, No. 2, Desember 2014, hal 286-316.

Henry and Richard Blackaby, Spiritual Leadership: Moving People on to God's Agenda. USA: Broadman \& Holman, 2001

Inge Klara Savitri, "Jakarta Paling Intoleran Ketiga, Ini Hasil Survei Selengkapnya") , diakes tanggal 28 Februari 2019, tersedia di 
https://metro.tempo.co/read/1153860/jakarta-paling-intoleran-ketiga-ini-hasilsurvei-selengkapnya/full\&view $=$ ok

Ionaes Rakhmat, Konflik Interpretasi Kitab Suci Kristen. Kompas, 1 Februari 2002: 25

Liem Khiem Yang, "Fundamentalisme dalam Gereja" dalam Fundamentalisme Agama-Agama dan Teknologi oleh Soetarman SP, Weinata Sairin, Ionaes Rakhmat, peny. Jakarta: BPKGM, 1993.

Martin L. Sinaga, "Meretas Jalan Teologi Agama-Agama di Indonesia (Theologia Religionum)", dalam Meretas Jalan Teologi Agama-Agama di Indonesia (Theologia Religionum) oleh Balitbang PGI, ed.akarta: BPKGM, 2000.

Wardani, "Pluralisme Agama dan Dialog Teologi" dalam Jurnal Khazanah, Januari Pebruari 2001, Nomor 55, hal. 46-58.

Zakharia J. Ngelow, "Islam dan Kristen dalam Politik Indonesia" dalam Meretas Jalan Teologi Agama-Agama di Indonesia (Theologia Religionum) oleh Balitbang PGI, ed. Jakarta: BPKGM, 2000. 